\title{
Structure and Properties of Cobalt-Exchanged H-ZSM5 Catalysts for Dehydrogenation and Dehydrocyclization of Alkanes
}

\author{
Wei Li, ${ }^{\ddagger}$ Sara Y. Yu, ${ }^{\ddagger}$ George D. Meitzner, ${ }^{\dagger}$ and Enrique Iglesia $*, \$$ \\ Department of Chemical Engineering, University of California at Berkeley, Berkeley, California 94720, and \\ Edge Analytical, 2126 Allen Blvd., Middleton, Wisconsin 53562
}

Received: June 12, 2000; In Final Form: November 14, 2000

\begin{abstract}
$\mathrm{Co} / \mathrm{H}-\mathrm{ZSM} 5$ catalysts with $\mathrm{Co} / \mathrm{Al}$ ratios of $0.09-0.22$ were prepared by aqueous exchange. Turnover rates for propane conversion to propene and to $\mathrm{C}_{6}-\mathrm{C}_{8}$ aromatics on these catalysts are about 10-fold higher than on H-ZSM5. The selectivities to propene, aromatics, and $\mathrm{H}_{2}$ are also higher on Co/H-ZSM5 than on $\mathrm{H}-\mathrm{ZSM} 5$. The rate of $\mathrm{D}_{2}$ exchange with $\mathrm{OH}$ groups increases with increasing $\mathrm{Co} / \mathrm{Al}$ ratio, suggesting that Co cations catalyze $\mathrm{D}_{2}$ dissociative chemisorption steps that limit the rate of isotopic exchange. Co cations also catalyze hydrogen recombinative desorption steps, which limit the rate of propane dehydrogenation and aromatization reactions. The density of residual zeolitic hydroxyls was measured by $\mathrm{D}_{2}-\mathrm{OH}$ isotopic exchange and by changes in the intensity of $\mathrm{OH}$ infrared bands as a function of $\mathrm{Co}$ content. $\mathrm{D}_{2}-\mathrm{OH}$ and infrared measurements showed that $\mathrm{Co}^{2+}$ cations replace $1.1-1.3$ zeolitic protons, suggesting the predominant presence of $\mathrm{Co}^{2+}-$ $\mathrm{O}-\mathrm{Co}^{2+}$ dimers, with some $\mathrm{Co}^{2+}$ monomers, each bridging two next-nearest neighbor $\mathrm{Al}$ sites. The location and structure of exchanged Co cations were probed using X-ray absorption spectroscopy (XAS) and temperature-programmed reduction (TPR). $\mathrm{No}_{2}$ consumption was detected up to $1273 \mathrm{~K}$ during TPR in any of the $\mathrm{Co} / \mathrm{H}-\mathrm{ZSM} 5$ samples, consistent with the absence of $\mathrm{CoO}_{x}$ crystallites, which reduce at $\sim 800 \mathrm{~K}$. In situ near-edge $\mathrm{X}$-ray absorption studies confirmed that $\mathrm{Co}$ species remain as divalent cations during exposure to $\mathrm{H}_{2}$ or $\mathrm{C}_{3} \mathrm{H}_{8}$ at $773 \mathrm{~K}$. Near-edge and fine structure analysis detected $\mathrm{Co}^{2+}$ cations with similar structure in all $\mathrm{Co} / \mathrm{H}-\mathrm{ZSM} 5$ samples $(\mathrm{Co} / \mathrm{Al}<0.22)$, and Co coordination changes from octahedral to tetrahedral upon sample dehydration at $773 \mathrm{~K}$ in He. Radial structure functions showed weak contributions from the first and second shells around Co. This reflects the nonuniform nature of the distance and orientation in $\mathrm{Al}-\mathrm{Al}$ nextnearest neighbor sites in ZSM5.
\end{abstract}

\section{Introduction}

H-ZSM5 zeolites exchanged with Zn or Ga cations catalyze propane dehydrocyclodimerization via bifunctional pathways involving Brønsted acid sites and exchanged cations. ${ }^{1-8}$ Cations increase propane conversion turnover rates and aromatics and $\mathrm{H}_{2}$ formation rates by catalyzing the recombinative desorption of $\mathrm{H}_{2}$, which occurs slowly on H-ZSM5. ${ }^{8,9}$ Hydrogen desorption steps are not quasi-equilibrated during alkane reactions on cation-exchanged H-ZSM5. Catalytic sites provided by cations relieve the kinetic bottleneck that limits the rate and selectivity of alkane dehydrocyclodimerization reactions.

Here, we describe the structure and the catalytic properties of Co-exchanged H-ZSM5 materials; these materials have not been previously reported as alkane dehydrocyclodimerization catalysts. In this study, the density and structure of Co species and of Brønsted acid sites was measured by combining temperature-programmed reduction (TPR), $\mathrm{D}_{2}-\mathrm{OH}$ isotopic exchange, infrared measurements, and X-ray absorption spectroscopy (XAS); their catalytic properties for propane dehydrocyclodimerization reactions were examined and compared with the behavior of H-ZSM5 and Zn/H-ZSM5.

$\mathrm{Co} / \mathrm{H}-\mathrm{ZSM} 5$ catalysts have been studied for the selective reduction of NO using alkanes. ${ }^{10-12}$ Thus, these materials appear

* Author to whom correspondence should be addressed. Fax: 510-6424778. E-mail: iglesia@cchem.berkeley.edu.

Edge Analytical.

$\div$ University of California at Berkeley. to contain catalytic sites for alkane activation reactions. Recently, we have shown that these materials also catalyze crosshydrogenation reactions of alkane-thiophene mixtures with the selective formation of $\mathrm{H}_{2} \mathrm{~S}$ using adsorbed hydrogen formed in alkane $\mathrm{C}-\mathrm{H}$ bond activation steps. ${ }^{13,14} \mathrm{Co} / \mathrm{H}-\mathrm{ZSM} 5$ materials have been previously prepared via aqueous 10,15 and solid-state exchange methods. ${ }^{16}$ The resulting species have been characterized by temperature-programmed reduction (TPR), ${ }^{15} \mathrm{X}$-ray diffraction (XRD), UV-visible, ${ }^{15,17}$ electron paramagnetic resonance (EPR), ${ }^{10} \mathrm{X}$-ray photoelectron (XPS), ${ }^{10,15}$ and X-ray absorption (XAS) spectroscopies. ${ }^{16}$ In these studies, the reported results were often limited to qualitative spectral information; also, the complementary information provided by these techniques was difficult to combine into a complete structural picture, because samples were prepared from different precursors and zeolitic materials in each study.

Here, we apply several complementary structural and chemical characterization methods to establish the structure and density of exchanged cations and of residual acidic $\mathrm{OH}$ groups in $\mathrm{Co} / \mathrm{H}-\mathrm{ZSM} 5$. The rate of reduction of $\mathrm{Co}^{2+}$ cations was used to detect $\mathrm{CoO}_{x}$ clusters and $\mathrm{CoO}$ or $\mathrm{Co}_{3} \mathrm{O}_{4}$ bulk crystallites. Infrared and isotopic exchange methods were used to measure the density of residual hydroxyls as the Co content was varied. Near-edge (XANES) and extended fine structure (EXAFS) $\mathrm{X}$-ray absorption methods were used to determine the local coordination of $\mathrm{Co}^{2+}$ cations. These measurements led to a consistent model of $\mathrm{Co}^{2+}$ monomers and dimers bridging two neighboring cation-exchange sites provided by next-nearest 
neighbor $\mathrm{Al}$ atoms in $\mathrm{Co} / \mathrm{H}-\mathrm{ZSM} 5(\mathrm{Co} / \mathrm{Al}=0.09-0.22)$. These bridging Co cations catalyze dissociative adsorption of $\mathrm{H}_{2}$ and the recombinative desorption of hydrogen adatoms and they lead to an increase in the rate of propane dehydrocyclodimerization reactions.

\section{Experimental Section}

Catalyst Synthesis. Co/H-ZSM5 samples were prepared by aqueous exchange of H-ZSM5 (prepared from Na-ZSM5; Zeochem, $\mathrm{Si} / \mathrm{Al}=14.5)$ with $\mathrm{Co}\left(\mathrm{NO}_{3}\right)_{2}\left(\mathrm{Co}\left(\mathrm{NO}_{3}\right)_{2} \cdot 6 \mathrm{H}_{2} \mathrm{O}\right.$, Aldrich, 99\%) aqueous solutions at $353 \mathrm{~K}$. The synthesis and characterization details of the H-ZSM5 sample are reported elsewhere. ${ }^{7,18}$ The Co content in the exchanged samples was controlled by varying the exchange time of H-ZSM5 $(\sim 2.5 \mathrm{~g}$ each) with a $0.05 \mathrm{M} \mathrm{Co}\left(\mathrm{NO}_{3}\right)_{2}$ solution between 2 and $16 \mathrm{~h}$, except for the sample with the highest cobalt loading $(\mathrm{Co} / \mathrm{Al}=$ 0.22 ), which was prepared by exchanging H-ZSM5 with a 0.5 $\mathrm{M} \mathrm{Co}\left(\mathrm{NO}_{3}\right)_{2}$ aqueous solution for $24 \mathrm{~h}$ at $353 \mathrm{~K}$. After exchange, the samples were filtered, washed with deionized water $(2 \mathrm{~L})$, dried in ambient air overnight at $393 \mathrm{~K}$, and treated in flowing dry air at $773 \mathrm{~K}\left(1.67 \mathrm{~cm}^{3} \mathrm{~s}^{-1}\right)$ for $20 \mathrm{~h}$. The Co contents were measured by atomic absorption (Galbraith Laboratories, Inc.); they ranged from 0.46 to $1.1 \mathrm{wt} \% \mathrm{Co}$, corresponding to $\mathrm{Co} / \mathrm{Al}$ atomic ratios of $0.09-0.22$. The higher Co contents reported in previous studies ${ }^{12,15}$ were not achieved here, even though the $\mathrm{Co}\left(\mathrm{NO}_{3}\right)_{2}$ concentration of the exchange solution was higher in our synthesis procedures than in the previous studies.

Characterization Methods. Reduction rate measurements were carried out using a $19.1 \% \mathrm{H}_{2} / \mathrm{Ar}$ (Matheson, certified standard) stream by measuring the $\mathrm{H}_{2}$ consumption rate using a modified Quantasorb apparatus (Quantachrome) equipped with a thermal conductivity detector. The system response was calibrated by reducing $\mathrm{CuO}$ (Fisher), $\mathrm{CoO}$ (Aldrich), and $\mathrm{Co}_{3} \mathrm{O}_{4}$ (Aldrich). The reducing gas mixture was metered using an electronic mass flow controller (Porter Instruments; $1.33 \mathrm{~cm}^{3}$ $\mathrm{s}^{-1}$ ). Temperature-programmed reduction (TPR) measurements were carried out using $0.25 \mathrm{~g}$ of $\mathrm{Co} / \mathrm{H}-\mathrm{ZSM} 5$ by increasing the sample temperature from ambient to $1273 \mathrm{~K}$ at a rate of 0.167 $\mathrm{K} \mathrm{s}^{-1}$. Reduction rates are reported as the molar $\mathrm{H}_{2}$ consumption rates per g-atom Co.

The density of zeolite $\mathrm{OH}$ groups remaining after ion exchange was obtained from the amount of $\mathrm{HD}$ and $\mathrm{H}_{2}$ evolved during exchange of $\mathrm{D}_{2}$ with $\mathrm{OH}$ groups, and also from the intensity of the infrared $\mathrm{OH}$ band in $\mathrm{Co} / \mathrm{H}-\mathrm{ZSM} 5$ samples. $\mathrm{D}_{2}-$ $\mathrm{OH}$ exchange experiments were carried out by raising the temperature of Co/H-ZSM5 or H-ZSM5 samples $(0.2 \mathrm{~g})$ to 773 $\mathrm{K}$ (973 K for H-ZSM5) at $0.167 \mathrm{~K} \mathrm{~s}^{-1}$ in a flowing $5 \% \mathrm{D}_{2} / \mathrm{Ar}$ mixture (Matheson, certified standard, $1.67 \mathrm{~cm}^{3} \mathrm{~s}^{-1}$ ) and measuring the concentrations of $\mathrm{HD}$ and $\mathrm{H}_{2}$ in the effluent using mass spectrometry (Leybold-Inficon, Transpector Model). This technique measures the total number of $\mathrm{OH}$ groups. When silanol groups or extraframework $\mathrm{Al}$ are minority species, this method gives the density of acidic hydroxyls associated with framework Al. Infrared spectra were obtained using a Fourier transform infrared spectrometer (Mattson, Research Series), an in situ Praying-Mantis diffuse reflectance attachment (Harrick Scientific, DRP-XXX), and a flow cell (Harrick Scientific, HVC-DR2) equipped with $\mathrm{NaCl}$ windows. Infrared spectra are reported in pseudo-absorbance units, calculated from the reflected intensity using the Kubelka-Munk function ${ }^{19}$ with $\mathrm{KBr}$ as the reference. Spectra were collected in the $400-4000 \mathrm{~cm}^{-1}$ frequency range with a resolution of $4 \mathrm{~cm}^{-1}$.

$\mathrm{X}$-ray absorption studies were performed at the Stanford Synchrotron Research Laboratory (SSRL) on beamlines 2-3 and
4-1 using an unfocused $\mathrm{Si}$ (111) double crystal upward-reflecting monochromator with parallel geometry. The intensities of the incident photon beam, the post-sample transmitted beam, and the transmitted beam after a reference Co foil were recorded using three $\mathrm{N}_{2}$-purged ionization chambers. The energy was calibrated by concurrently measuring the sample spectrum and that for a Co foil (absorption edge energy of $7709 \mathrm{eV}$ ). X-ray absorption spectra were measured using an in-situ capillary cell and a portable gas manifold; ${ }^{20} \mathrm{X}$-ray absorption data were analyzed using WinXAS (version 1.2). ${ }^{21} \mathrm{~A}$ linear fit to the preedge region was subtracted from the entire spectrum, and then the spectrum was normalized using a fifth-order polynomial fit to the postedge (EXAFS) region. The energy scale for conversion to $k$ (wave vector) space was calibrated by defining the first inflection point available in all the spectra, or the first inflection point beyond the preedge peak (if present), as the absorption edge. After conversion to $k$-space, the EXAFS weighted by $k^{1}$ was Fourier transformed between 2.5 and 15 $\AA^{-1}$ using a Hanning's window function. Due to the weak EXAFS signals from Co in these samples, only one-shell fits to Co K-edge EXAFS were carried out for fresh and dehydrated samples. The single shell of oxygen neighbors was generated with FEFF 6.0.

Propane Reaction Rate and Selectivity on Co/H-ZSM5. The rate and the selectivity of propane reactions were measured in a recirculating batch reactor at $773 \mathrm{~K} .{ }^{8}$ The recirculation rate of the reactant flow was greater than $2 \mathrm{~cm}^{3} \mathrm{~s}^{-1}$ in order to ensure low propane conversions per pass $(<1 \%)$. Samples $(\sim 0.08 \mathrm{~g})$ were treated in flowing air $\left(1.67 \mathrm{~cm}^{3} \mathrm{~s}^{-1}\right)$ for $1 \mathrm{~h}$ at $773 \mathrm{~K}$ before propane reactions at $773 \mathrm{~K}$ and $110 \mathrm{kPa}$ using a $20 \%$ $\mathrm{C}_{3} \mathrm{H}_{8} / \mathrm{He}$ (Praxair, certified mixture) recirculating reactant mixture. Reactant and product concentrations were measured as a function of contact time by injecting $0.2 \mathrm{~cm}^{3}$ syringe gas samples into a gas chromatograph (Hewlett-Packard 5890) equipped with a capillary column (Hewlett-Packard, HP-1 methyl-silicone column, $50 \mathrm{~m}, 0.32-\mathrm{mm}$ diameter, $1.05 \mu \mathrm{m}$ film thickness) and a flame ionization detector. Batch reactor data are shown as turnovers (moles of propane converted per g-atom $\mathrm{Al}$ ) or site-yields (moles of propane appearing as a given product per g-atom Al in samples) as a function of contact time. The slope of these plots gives the propane turnover rate or product site-time yield. Product selectivities are reported on a carbon basis, as the percentage of the converted propane appearing as a given product. $\mathrm{H}_{2}$ selectivity is calculated from a hydrogen balance, as the percentage of the $\mathrm{H}$ atoms in the converted propane that do not appear within the observed hydrocarbon products.

\section{Results and Discussion}

Reduction of Co/H-ZSM5 in $\mathbf{H}_{2}$. The reduction of $\mathrm{Co} / \mathrm{H}-$ ZSM5 in $\mathrm{H}_{2}$ was used to probe the reducibility of the Co species. $\mathrm{H}_{2}$ consumption rates during reduction of $\mathrm{CoO}$ and $\mathrm{Co}_{3} \mathrm{O}_{4}$ and of $\mathrm{Co} / \mathrm{H}-\mathrm{ZSM} 5$ samples with $\mathrm{Co} / \mathrm{Al}$ ratios of $0.09-0.22$ are shown in Figure 1. $\mathrm{CoO}$ and $\mathrm{Co}_{3} \mathrm{O}_{4}$ powders reduced to $\mathrm{Co}$ metal below $800 \mathrm{~K}$ and the amount of $\mathrm{H}_{2}$ consumed corresponded to $\mathrm{H}_{2} /$ Co ratios of 0.93 and 1.31 , respectively; these values are very similar to those expected from stoichiometric complete reduction of $\mathrm{CoO}(1.0)$ and $\mathrm{Co}_{3} \mathrm{O}_{4}$ (1.33) to Co metal. In contrast, the amount of $\mathrm{H}_{2}$ consumed during heating of $\mathrm{Co} /$ $\mathrm{H}$-ZSM5 samples to $1273 \mathrm{~K}$ corresponded to $\mathrm{H}_{2} / \mathrm{Co}$ ratios less than 0.01. Thus, Co species in these Co/H-ZSM5 samples remained essentially unreduced even at $1273 \mathrm{~K}$ for $\mathrm{Co} / \mathrm{Al}$ ratios of $0.09-0.22$. These data show that $\mathrm{CoO}_{x}$ clusters or crystallites are not present and that all $\mathrm{Co}^{2+}$ cations reside as dispersed species, presumably at cation exchange sites. 


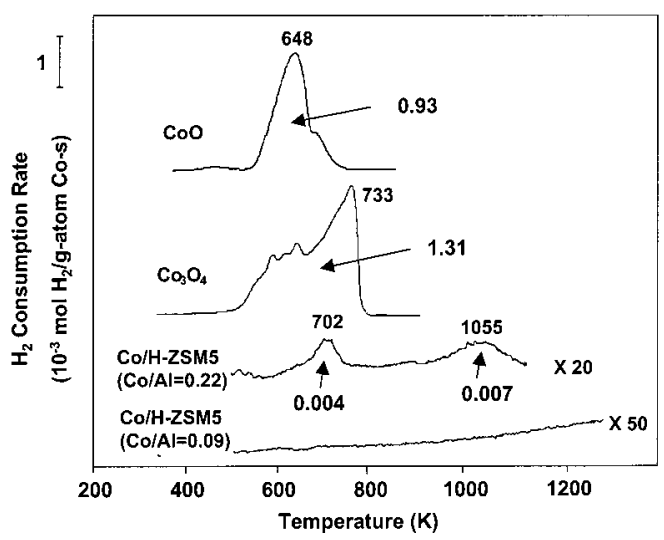

Figure 1. $\mathrm{H}_{2}$ consumption rates during temperature-programmed reduction of $\mathrm{CoO}, \mathrm{Co}_{3} \mathrm{O}_{4}$, and $\mathrm{Co} / \mathrm{H}-\mathrm{ZSM} 5(\mathrm{Co} / \mathrm{Al}=0.09$ and 0.22$)$ [19.1\% $\left.\mathrm{H}_{2} / \mathrm{Ar}, 1.33 \mathrm{~cm}^{3} \mathrm{~s}^{-1}, 0.167 \mathrm{~K} \mathrm{~s}^{-1}\right]$. The numbers next to the plot indicate the measured amount of $\mathrm{H}_{2}$ consumed normalized to $\mathrm{Co}$ content, expressed as $\mathrm{H}_{2} / \mathrm{Co}$ ratios.

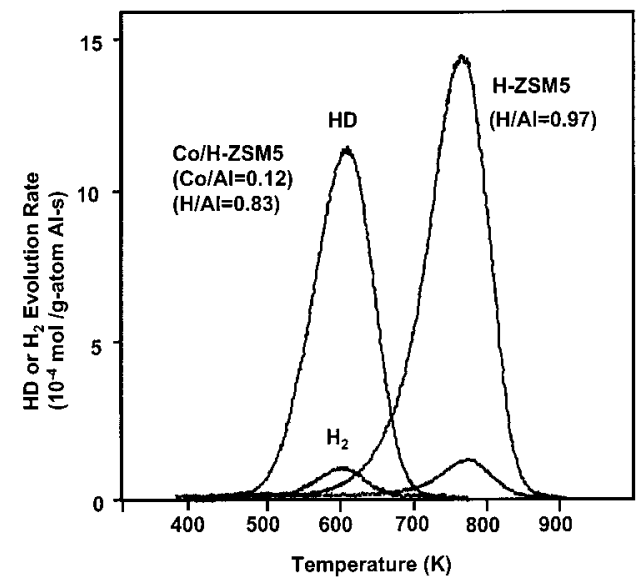

Figure 2. $\mathrm{HD}$ and $\mathrm{H}_{2}$ formation rates during isotopic $\mathrm{D}_{2}-\mathrm{OH}$ exchange experiments on $\mathrm{H}-\mathrm{ZSM} 5$ and $\mathrm{Co} / \mathrm{H}-\mathrm{ZSM} 5(\mathrm{Co} / \mathrm{Al}=0.12)\left[5 \% \mathrm{D}_{2} / \mathrm{Ar}\right.$, $1.67 \mathrm{~cm}^{3} \mathrm{~s}^{-1}, 0.167 \mathrm{~K} \mathrm{~s}^{-1}$.

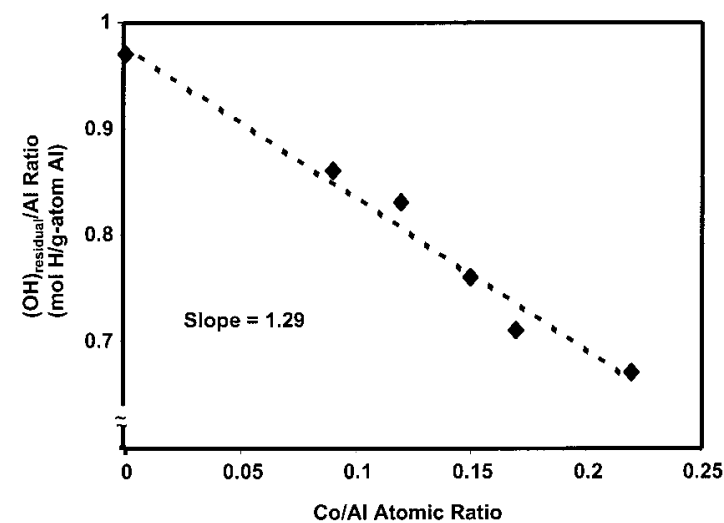

Figure 3. Density of residual hydroxyls as a function of $\mathrm{Co} / \mathrm{Al}$ ratio from $\mathrm{D}_{2}-\mathrm{OH}$ exchange experiments $\left[5 \% \mathrm{D}_{2} / \mathrm{Ar}, 1.67 \mathrm{~cm}^{3} \mathrm{~s}^{-1}, 0.167\right.$ $\mathrm{K} \mathrm{s}^{-1}$.

Exchanged $\mathrm{Co}^{2+}$ cations do not reduce in $\mathrm{H}_{2}$ even at 1273 $\mathrm{K}$, as also observed for exchanged $\mathrm{Zn}^{2+}$ in $\mathrm{Zn} / \mathrm{H}-\mathrm{ZSM} 5$. $^{7}$ The small but detectable $\mathrm{H}_{2}$ consumption peaks at 702 and $1055 \mathrm{~K}$ for the sample with the highest Co loading $\left(\mathrm{Co} / \mathrm{Al}=0.22 ; \mathrm{H}_{2} /\right.$ $\mathrm{Co}<0.01$; Figure 1) may reflect the incipient formation of $\mathrm{CoO}_{x}$ clusters at high $\mathrm{Co}$ contents; these external $\mathrm{CoO}_{x}$ clusters appear to be responsible for the difficulties encountered in previous studies in establishing an accurate Co exchange stoichiometry. ${ }^{16}$ The reduction peak at $702 \mathrm{~K}$ resembles that

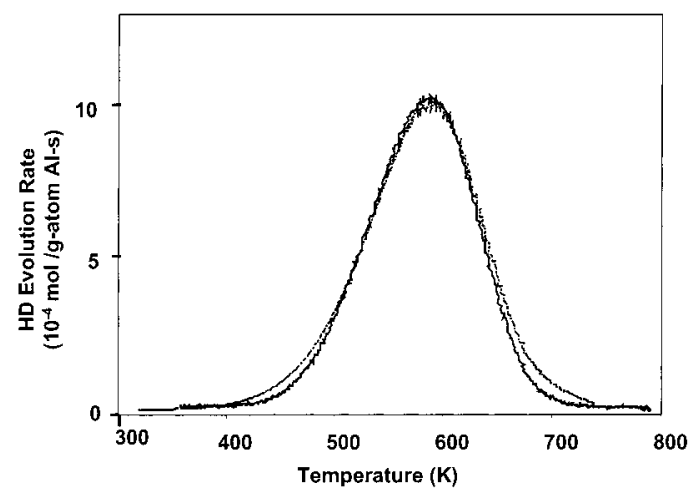

Figure 4. Comparison of the measured and calculated values of the $\mathrm{HD}$ evolution rate $\left[\mathrm{Co} / \mathrm{Al}=0.12,5 \% \mathrm{D}_{2} / \mathrm{Ar}, 1.67 \mathrm{~cm}^{3} \mathrm{~s}^{-1}, 0.167 \mathrm{~K}\right.$ $\left.\mathrm{s}^{-1}\right]$. The thick solid line is the measured results, and the thin line is the calculated results.

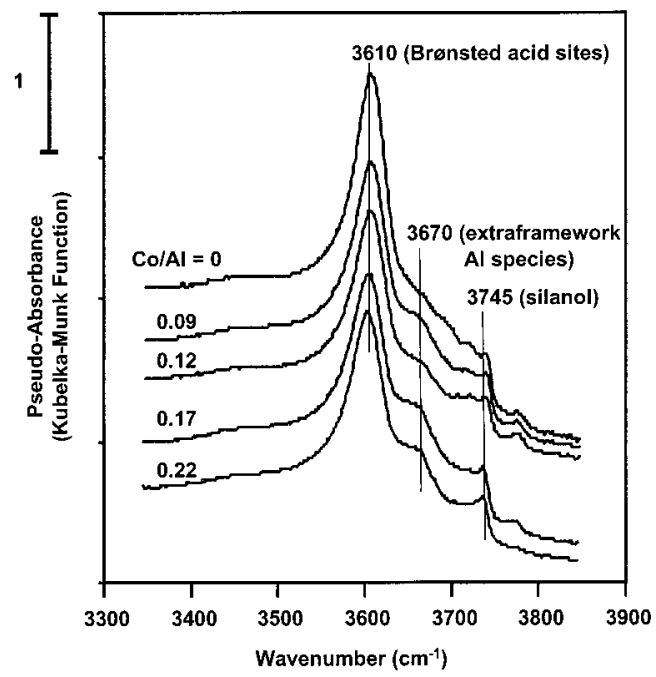

Figure 5. Infrared spectra of the $\mathrm{OH}$ stretching region for $\mathrm{H}-\mathrm{ZSM} 5$ and $\mathrm{Co} / \mathrm{H}-\mathrm{ZSM} 5(\mathrm{Co} / \mathrm{Al}=0.09-0.22)$.

observed at $733 \mathrm{~K}$ for the reduction of $\mathrm{Co}_{3} \mathrm{O}_{4}$, suggesting the incipient formation of bulk $\mathrm{Co}_{3} \mathrm{O}_{4}$. The $\mathrm{H}_{2}$ consumption peak at $1055 \mathrm{~K}$ corresponds to traces of Co species that are less reducible than bulk cobalt oxides, possibly small $\mathrm{CoO}_{x}$ clusters interacting strongly with the external surface of ZSM5 crystals or Co silicates formed by interactions with silanol groups. The reduction process detected above $1000 \mathrm{~K}$ can also reflect changes in the coordination of exchanged $\mathrm{Co}^{2+}$ as the zeolite structure collapses, leading to the formation of reducible $\mathrm{CoO}_{x}$ crystallites. We conclude from these reduction measurements that more than $99 \%$ of the $\mathrm{Co}^{2+}$ cations in all of the $\mathrm{Co} / \mathrm{H}-$ ZSM5 samples of this study exist in an environment that prevents their reduction. Such an environment is provided by cation exchange sites, which stabilize $\mathrm{Co}^{2+}$ against reduction, either by forming strong $\mathrm{Co}-\mathrm{O}-\mathrm{Al}$ bonds or by eliminating the possibility of the concerted agglomeration of $\mathrm{Co}^{\circ}$ required to nucleate stable Co metal clusters.

Previous temperature-programmed studies of $\mathrm{Co} / \mathrm{H}-\mathrm{ZSM} 5$ $(\mathrm{Co} / \mathrm{Al}=0.10-0.15)$ prepared by aqueous exchange ${ }^{15}$ showed a $\mathrm{H}_{2}$ consumption peak at $\sim 1000 \mathrm{~K}$, which was assigned to the reduction of $\mathrm{Co}^{2+}$ ions at cation exchange sites. No quantitative measure of the amount of $\mathrm{H}_{2}$ consumed as a function of the Co content was reported. A similar $\mathrm{H}_{2}$ consumption peak at 1055 $\mathrm{K}$ was observed in this study; we have assigned this peak to the reduction of $\mathrm{CoO}_{x}$ species. This peak cannot arise from the reduction of exchanged Co cations, because the amount of $\mathrm{H}_{2}$ consumed would account for the reduction of less than $1 \%$ of 
SCHEME 1: Steps of $\mathrm{D}_{2}$-OH Exchange

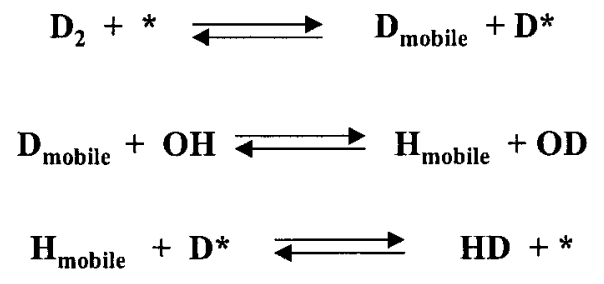

the Co in these samples. The Co/H-ZSM5 samples in the previous study ${ }^{15}$ may have included significant amounts of $\mathrm{CoO}_{x}$ clusters on external zeolite surfaces. These differences may reflect the high silanol concentration in the H-ZSM5 sample used in this study, ${ }^{15}$ as evidenced by the reported infrared spectrum. These external silanol groups may allow strong interactions with hydrated Co species during aqueous exchange and lead to the formation of $\mathrm{CoO}_{x}$ clusters after treatment in air at high temperatures.

Density of Residual OH Groups after Exchange: Isotopic $\mathbf{D}_{2}-\mathbf{O H}$ Exchange. $\mathrm{HD}$ and $\mathrm{H}_{2}$ were formed as $\mathrm{H}$ atoms in the hydroxyl groups are replaced with $\mathrm{D}$ atoms when $\mathrm{Co} / \mathrm{H}$ ZSM5 samples are exposed to $\mathrm{D}_{2}$ at temperatures above $450 \mathrm{~K}$ (Figure 2). HD was the predominant exchange product, but some $\mathrm{H}_{2}$ was formed by secondary exchange of formed HD with the remaining $\mathrm{OH}$ groups. The presence of $\mathrm{Co}^{2+}$ species increased the rate of $\mathrm{D}_{2}-\mathrm{OH}$ isotopic exchange and decreased the temperature of the HD evolution peak from $761 \mathrm{~K}$ on $\mathrm{H}-\mathrm{ZSM} 5$ to $617 \mathrm{~K}$ on $\mathrm{Co} / \mathrm{H}-\mathrm{ZSM} 5(\mathrm{Co} / \mathrm{Al}=0.12)$. On $\mathrm{H}-\mathrm{ZSM} 5$, the $(\mathrm{OH}) / \mathrm{Al}$ ratio was 0.97 , suggesting the substantial absence of extraframework $\mathrm{AlO}_{x}$ species, a finding confirmed by ${ }^{27} \mathrm{Al} \mathrm{NMR}$ measurements. ${ }^{18}$ Also, infrared measurements indicated that there are few silanol groups on the external surface of the H-ZSM5 sample; ${ }^{22}$ therefore, the predominant $\mathrm{OH}$ groups present in the H-ZSM5 sample and detected by the $\mathrm{D}_{2}-\mathrm{OH}$ exchange process are acidic hydroxyls associated with framework $\mathrm{Al}$ cations. As a result, $\mathrm{D}_{2}-\mathrm{OH}$ isotopic titrations accurately measure the number of exchange sites that retain a proton after exchange with $\mathrm{Co}^{2+}$ cations. The number of residual $\mathrm{OH}$ groups, $(\mathrm{OH})_{\text {residual }} / \mathrm{Al}$ ratio, is shown as a function of the atomic $\mathrm{Co} / \mathrm{Al}$ ratio in Figure 3 . The $(\mathrm{OH})_{\text {residual }} / \mathrm{Al}$ ratio decreased linearly with increasing $\mathrm{Co} / \mathrm{Al}$ ratio; the slope of this linear response is $\sim 1.3$, suggesting that Co cations may exist as a mixture of several structures that replace between zero and two protons per Co atom. The linear dependence indicates that the exchange stoichiometry, and therefore the relative abundance of various exchanged cation structures, remains unchanged as the $\mathrm{Co} / \mathrm{Al}$ ratio was varied $(0.09-0.22)$.

$\mathrm{D}_{2}-\mathrm{OH}$ exchange requires the dissociation of $\mathrm{D}_{2}$ to form surface mobile D species, which then exchange with $\mathrm{OH}$ groups (Scheme 1). The exchange step of the mobile D species with the surface hydroxyls is quasi-equilibrated. Therefore, the measured HD evolution rates are given by the product of the $\mathrm{D}_{2}$ dissociation rate and the probability that mobile $\mathrm{D}$ species find an unexchanged $\mathrm{OH}$ group among all surface hydroxyls ( $x$ $\left.=[\mathrm{OH}]_{\text {remaining }} /[\mathrm{OH}]_{\text {initial }}\right)$; this leads to first-order kinetics in $\mathrm{OH}$ surface density (Figure 4), as previously shown for $\mathrm{Zn} / \mathrm{H}$ ZSM5 samples. ${ }^{7}$ As a result, the measured HD evolution rates reflect the rates of $\mathrm{D}_{2}$ dissociation. The kinetic parameters corresponding to this first-order evolution peak were calculated by a regression fit of the measured rates in the range of $0.05<$ $x<0.95$; the activation energies were $80 \mathrm{~kJ} \mathrm{~mol}^{-1}$ and $59 \mathrm{~kJ}$ $\mathrm{mol}^{-1}$ on H-ZSM5 and Co/H-ZSM5 (Co/Al $\left.=0.12\right)$, respectively. A representative regression fit is shown in Figure 4. The activation energy on $\mathrm{Co} / \mathrm{H}-\mathrm{ZSM} 5$ samples did not change

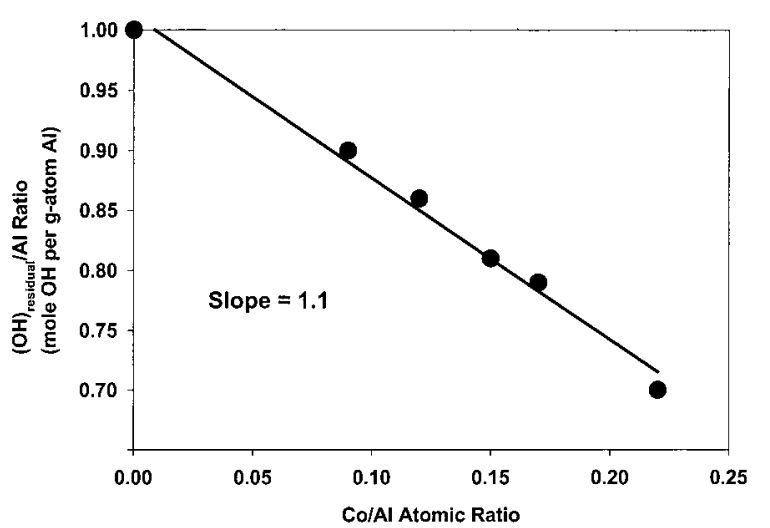

Figure 6. Density of residual hydroxyls obtained from infrared spectra for $\mathrm{Co} / \mathrm{H}-\mathrm{ZSM} 5$ with varying $\mathrm{Co} / \mathrm{Al}$ ratio.

with $\mathrm{Co} / \mathrm{Al}$ ratio $\left(57-63 \mathrm{~kJ} \mathrm{~mol}^{-1}\right)$, suggesting that the rate depends on the intrinsic kinetics of $\mathrm{D}_{2}$ dissociation on a distribution of $\mathrm{Co}^{2+}$ cation structures, which do not depend on the $\mathrm{Co} / \mathrm{Al}$ ratio. The lower activation energy on Co/H-ZSM5 samples compared to the $\mathrm{H}-\mathrm{ZSM} 5$ indicates that the addition of Co to H-ZSM5 substantially decreases the activation energy for the $\mathrm{D}_{2}$ dissociation step, a necessary and rate-controlling step in the $\mathrm{D}_{2}-\mathrm{OH}$ exchange reaction. As a result, Co species must also catalyze the microscopic reverse of the $\mathrm{D}_{2}$ dissociation step, the recombinative desorption of hydrogens, a step that limits propane reactions on cation-exchanged H-ZSM5. Similar effects of $\mathrm{Zn}$ cations on $\mathrm{D}_{2}-\mathrm{OH}$ exchange rates and activation energies were observed on Zn/H-ZSM5 catalysts. ${ }^{7}$

Density of Residual Hydroxyls from Infrared Measurements. Infrared spectra of $\mathrm{Co} / \mathrm{H}-\mathrm{ZSM} 5$ samples were measured in order to detect changes in the density of acidic hydroxyls after Co exchange. Three types of hydroxyl groups were detected by infrared in H-ZSM5: acidic hydroxyls associated with framework $\mathrm{Al}(\mathrm{Si}-\mathrm{OH}-\mathrm{Al})$, extraframework $\mathrm{AlO}_{x}-\mathrm{H}$ species, and silanol ( $\mathrm{Si}-\mathrm{OH})$ groups on external ZSM5 surfaces, with $\mathrm{OH}$ stretching bands at 3610,3675 , and $3745 \mathrm{~cm}^{-1}$, respectively. ${ }^{23,24}$ Figure 5 shows the $\mathrm{OH}$ stretching infrared region for $\mathrm{Co} / \mathrm{H}-\mathrm{ZSM} 5(\mathrm{Co} / \mathrm{Al}=0.09-0.22)$ and $\mathrm{H}-\mathrm{ZSM} 5$ samples. H-ZSM5 contains predominantly acidic $\mathrm{OH}$ groups with very few $\mathrm{AlO}_{x}-\mathrm{H}$ or $\mathrm{Si}-\mathrm{OH}$ groups; this is consistent with the $\mathrm{OH} / \mathrm{Al}$ ratios near unity obtained from $\mathrm{D}_{2}-\mathrm{OH}$ exchange measurements. The intensity of the $\mathrm{OH}$ band at 3610 $\mathrm{cm}^{-1}$ in $\mathrm{Co} / \mathrm{H}-\mathrm{ZSM} 5(\mathrm{Co} / \mathrm{Al}=0-0.22)$, calibrated using the framework vibration bands at $500-1600 \mathrm{~cm}^{-1}$ as an internal standard, was normalized to the corresponding intensity in the unexchanged H-ZSM5 sample; this ratio was used to estimate the fraction of the acidic $\mathrm{OH}$ groups that remain after exchange, $[\mathrm{OH}]_{\text {residual }} / \mathrm{Al}$. This ratio decreased linearly with increasing $\mathrm{Co} /$ Al ratio with a slope of $\sim 1.1(\mathrm{OH})_{\text {removed }}$ per Co (Figure 6). Thus, it appears that Co exchange can replace either zero, one, or two $\mathrm{H}^{+}$and that the exchange stoichiometry is essentially unaffected by the $\mathrm{Co} / \mathrm{Al}$ ratio for values between 0.09 and 0.22 . These conclusions are consistent with the $\mathrm{D}_{2}-\mathrm{OH}$ exchange data shown in Figure 3. The intensities of the minority $\mathrm{O}-\mathrm{H}$ bands for $\mathrm{AlO}_{x}-\mathrm{H}$ and $\mathrm{Si}-\mathrm{OH}$ species were not significantly affected by $\mathrm{Co}$ exchange, indicating that $\mathrm{Co}^{2+}$ cations do not interact with such species during exchange. It was reported previously ${ }^{16}$ that the removal of acid sites, detected by infrared measurements of $\mathrm{OH}$ bands, was complete only for $\mathrm{Co} / \mathrm{Al}$ ratios greater than one, leading these authors to conclude that exchange occurred with the replacement of one $\mathrm{H}^{+}$with each $\mathrm{Co}^{2+}$. No evidence, however, was reported that all the Co atoms actually resided at cation exchange sites. The presence of $\mathrm{CoO}_{x}$ clusters 


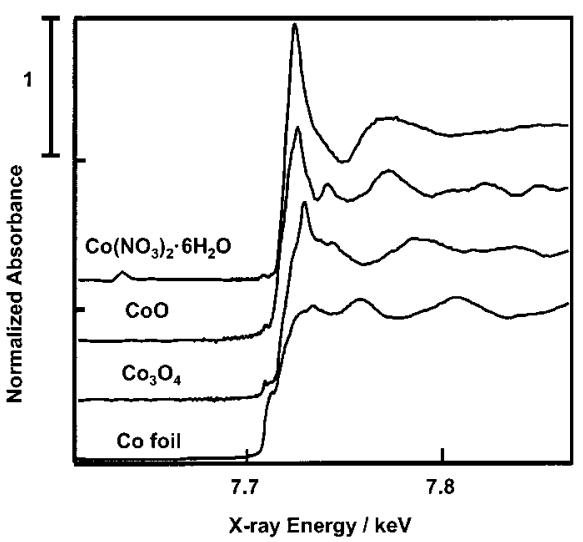

Figure 7. Near-edge spectra of Co metal, $\mathrm{CoO}, \mathrm{Co}_{3} \mathrm{O}_{4}$, and $\mathrm{Co}\left(\mathrm{NO}_{3}\right)_{2}$. $6 \mathrm{H}_{2} \mathrm{O}$ standards at ambient conditions.

TABLE 1: Co K-Edge Energy Position for Co/H-ZSM5 Samples with Respect to That for Co Metal Foil (7.7090 $\mathbf{k e V})^{a}$

\begin{tabular}{lc}
\hline \multicolumn{1}{c}{ compound } & edge position $\Delta E(\mathrm{eV})$ \\
\hline $\mathrm{Co}$ foil & 0 \\
$\mathrm{CoO}$ & 11.9 \\
$\mathrm{Co} \mathrm{O}_{4}$ & 12.9 \\
$\mathrm{Co}\left(\mathrm{NO}_{3}\right) \cdot 6 \mathrm{H}_{2} \mathrm{O}$ & 13.5 \\
$\mathrm{Co} / \mathrm{H}-\mathrm{ZSM} 5(\mathrm{Co} / \mathrm{Al}=0.09)$ & 13.1 \\
$\mathrm{Co} / \mathrm{H}-\mathrm{ZSM} 5(\mathrm{Co} / \mathrm{Al}=0.12)$ & 13.2 \\
$\mathrm{Co} / \mathrm{H}-\mathrm{ZSM} 5(\mathrm{Co} / \mathrm{Al}=0.17)$ & 13.1 \\
$\mathrm{Co} / \mathrm{H}-\mathrm{ZSM} 5(\mathrm{Co} / \mathrm{Al}=0.22)$ & 13.2
\end{tabular}

${ }^{a}$ The edge position is defined as the first inflection point.

or bulk crystallites can lead to apparent Co content requirements larger than the stoichiometric amount needed for the complete titration of exchange sites.

Near-Edge and Extended Fine Structure X-ray Absorption Spectra (XAS). Figure 7 shows the near-edge $\mathrm{X}$-ray absorption spectra (XANES) for $\mathrm{Co}$ metal, $\mathrm{CoO}, \mathrm{Co}_{3} \mathrm{O}_{4}$, and $\mathrm{Co}\left(\mathrm{NO}_{3}\right)_{2} \cdot 6 \mathrm{H}_{2} \mathrm{O}$ standard materials at ambient conditions. $\mathrm{Co}_{3} \mathrm{O}_{4}$ shows a pre-edge peak, corresponding to $1 \mathrm{~s}$ to $3 \mathrm{~d}$ transitions that are forbidden in the centrosymmetric octahedral structures present in $\mathrm{Co}$ and $\mathrm{CoO} .{ }^{25}$ Distortion of this octahedral symmetry allows this transition to occur in $\mathrm{Co}_{3} \mathrm{O}_{4}$, which has $2 / 3$ of its Co atoms in octahedral sites and the rest in tetrahedral sites. ${ }^{26}$ As a result, a pre-edge feature is clearly detected in $\mathrm{Co}_{3} \mathrm{O}_{4}$ (Figure 7). The position of the absorption edge, defined as the first inflection point in the absorption edge for each sample reflects the Co oxidation state. ${ }^{27}$ The absorption edge shifts to lower energy as $\mathrm{Co}^{2+}$ is reduced to Co metal. ${ }^{25}$ Co K-edge energies are reported for all the Co/H-ZSM5 and for the reference Co compounds in Table 1 . The absorption edge in Co/H-ZSM5 samples is $\sim 13 \mathrm{eV}$ higher than for Co foil and it is similar to that in $\mathrm{Co}\left(\mathrm{NO}_{3}\right)_{2} \cdot 6 \mathrm{H}_{2} \mathrm{O}$, consistent with the predominant presence of $\mathrm{Co}^{2+}$ cations in all $\mathrm{Co} / \mathrm{H}-\mathrm{ZSM} 5$ samples.

The near-edge spectra of all fresh (air-exposed) Co/H-ZSM5 samples $(\mathrm{Co} / \mathrm{Al}=0.09-0.22)$ are very similar (Figure 8 ), suggesting that $\mathrm{Co}^{2+}$ species reside at similar locations in all samples. The near-edge spectra of all air-exposed Co/H-ZSM5 samples resemble that of the $\mathrm{Co}\left(\mathrm{NO}_{3}\right)_{2} \cdot 6 \mathrm{H}_{2} \mathrm{O}$ standard (Figure 8), suggesting that hydrated $\mathrm{Co}^{2+}$ cations acquire octahedral coordination by adsorbing water molecules. $\mathrm{CoO}$ or $\mathrm{Co}_{3} \mathrm{O}_{4}$ standards show intense features corresponding to multiple coordination shells in the radial structure function (Figure 9). In contrast, the radial structure function for $\mathrm{Co} / \mathrm{H}-\mathrm{ZSM} 5$ samples shows few structural features beyond the first oxygen coordination shell (Figure 10), suggesting the substantial absence of

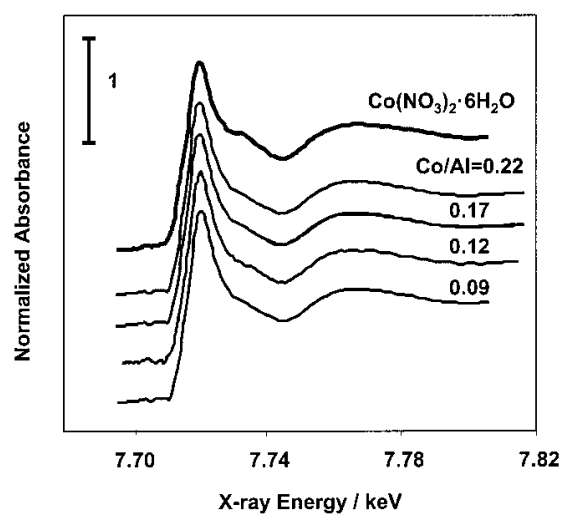

Figure 8. Near-edge spectra of fresh (hydrated) $\mathrm{Co} / \mathrm{H}-\mathrm{ZSM} 5$ samples $(\mathrm{Co} / \mathrm{Al}=0.09-0.22)$. The near-edge spectrum of $\mathrm{Co}\left(\mathrm{NO}_{3}\right)_{2} \cdot 6 \mathrm{H}_{2} \mathrm{O}$ standard is also shown for comparison.

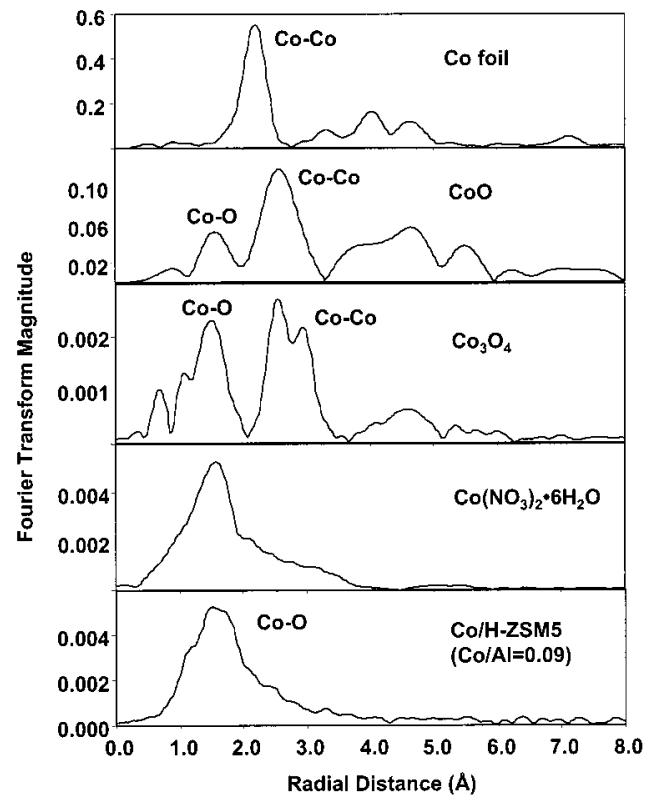

Figure 9. Radial structure functions of $\mathrm{Co}$ species in $\mathrm{Co}$ metal, $\mathrm{CoO}$, $\mathrm{Co}_{3} \mathrm{O}_{4}$, and $\mathrm{Co}\left(\mathrm{NO}_{3}\right)_{2} \cdot 6 \mathrm{H}_{2} \mathrm{O}$ standards.

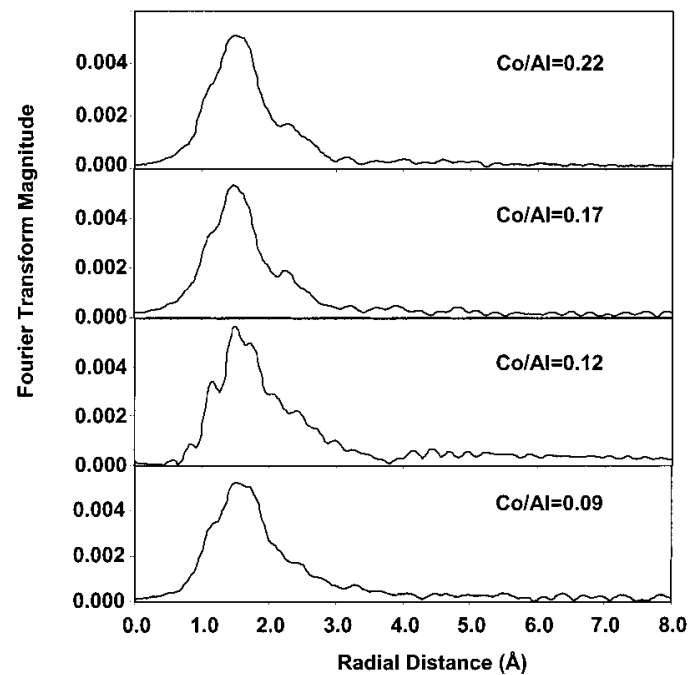

Figure 10. Radial structure functions of fresh (hydrated) Co/H-ZSM5 samples $(\mathrm{Co} / \mathrm{Al}=0.09-0.22)$ at ambient conditions.

longer-range coordination shells. Thus, $\mathrm{Co}^{2+}$ cations appear to reside at cation exchange sites as dispersed species and the location of the framework $\mathrm{Al}$ and $\mathrm{Si}$ atoms in more distant 


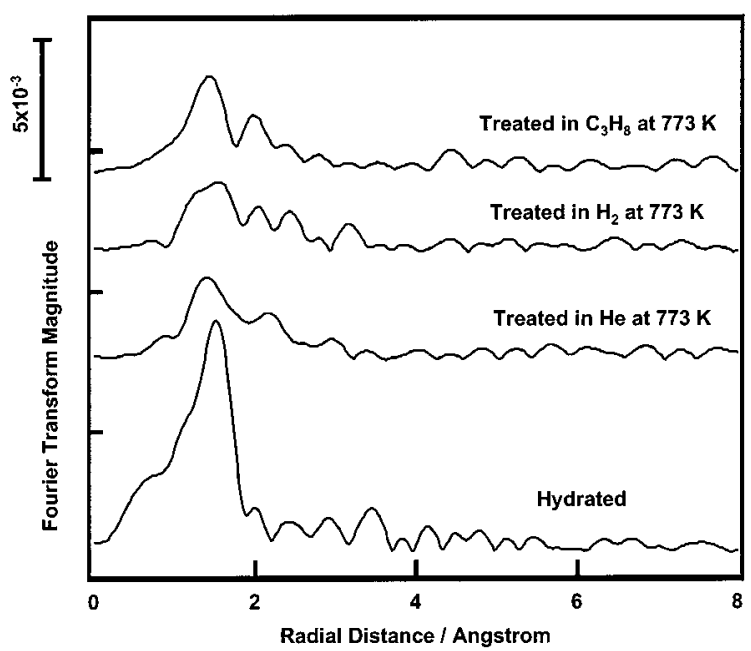

Figure 11. Radial structure functions of Co species in Co/H-ZSM5 $(\mathrm{Co} / \mathrm{Al}=0.22)$ in varying conditions: fresh(hydrated), in $\mathrm{He}$ at 773 $\mathrm{K}$, in $\mathrm{H}_{2}$ at $773 \mathrm{~K}$, and in $\mathrm{C}_{3} \mathrm{H}_{8}$ at $773 \mathrm{~K}$.

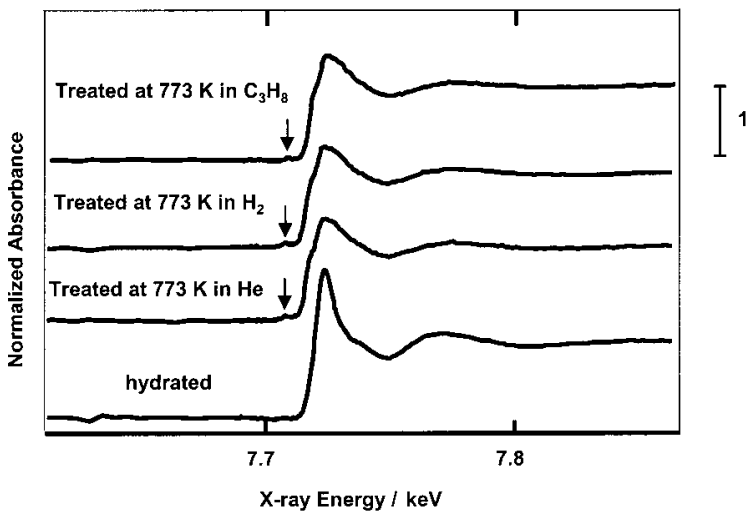

Figure 12. Near-edge spectra for $\mathrm{Co} / \mathrm{H}-\mathrm{ZSM} 5(\mathrm{Co} / \mathrm{Al}=0.22)$ : fresh(hydrated) (a), in $\mathrm{He}$ at $773 \mathrm{~K}(\mathrm{~b})$, in $\mathrm{H}_{2}$ at $773 \mathrm{~K}(\mathrm{c})$, and in $\mathrm{C}_{3} \mathrm{H}_{8}$ at $773 \mathrm{~K}(\mathrm{~d})$.

coordination spheres is highly nonuniform. As a result, neighbors beyond the bonded oxygen atoms do not contribute significantly to the radial structure function of $\mathrm{Co} / \mathrm{H}-\mathrm{ZSM} 5$ samples. The radial structure functions of fresh (air-exposed) $\mathrm{Co} / \mathrm{H}-\mathrm{ZSM} 5$ samples resemble that of $\mathrm{Co}\left(\mathrm{NO}_{3}\right)_{2} \cdot 6 \mathrm{H}_{2} \mathrm{O}$, with a broad $\mathrm{Co}-\mathrm{O}$ shell at $\sim 1.7 \AA$, indicating that $\mathrm{Co}^{2+}$ cations reside in an octahedral structure with the $\mathrm{Co}-\mathrm{O}$ first coordination shell satisfied by framework $\mathrm{O}$-atoms and by oxygen atoms in adsorbed $\mathrm{H}_{2} \mathrm{O}$ (Figure 9). The radial structure functions in $\mathrm{Co} /$ H-ZSM5 samples with varying Co content are similar, indicating that they contain Co species with similar structure (Figure 10).

After dehydration in $\mathrm{He}$ at $773 \mathrm{~K}$, the first coordination shell in the radial structure function of $\mathrm{Co} / \mathrm{H}-\mathrm{ZSM} 5(\mathrm{Co} / \mathrm{Al}=0.22)$ became weaker, suggesting that the removal of water changes the local environment around $\mathrm{Co}^{2+}$ (Figure 11). Concurrently, a weak preedge feature appeared in the near-edge spectrum (Figure 12), indicating that the local symmetry of Co coordination changes from octahedral in hydrated samples to a less symmetric structure as coordinated water molecules are removed. The resulting distortion from the centrosymmetric octahedral structure allows $1 \mathrm{~s} \rightarrow 3 \mathrm{~d}$ transitions to occur (Figure 12). This reversible effect of adsorbed water also provides indirect evidence for the dispersed nature of $\mathrm{Co}^{2+}$ species, which allows most of the $\mathrm{Co}^{2+}$ centers to be accessible at surfaces and to interact with water.

Treatments in $\mathrm{H}_{2}$ or $\mathrm{C}_{3} \mathrm{H}_{8}$ up to $773 \mathrm{~K}$ did not change the near-edge spectrum (Figure 12), suggesting that the local Co
TABLE 2: Co K-Edge Energy Position with Respect to That for Co Metal Foil $(7709 \mathrm{eV})$ for $\mathrm{Co} / \mathrm{H}-\mathrm{ZSM} 5(\mathrm{Co} / \mathrm{Al}=\mathbf{0 . 2 2})$ after Treatments at $773 \mathrm{~K}$ in $\mathrm{He}, \mathrm{H}_{2}$, or $\mathrm{C}_{3} \mathrm{H}_{8}{ }^{a}$

\begin{tabular}{lc}
\hline conditions & edge energy $\Delta E(\mathrm{eV})$ \\
\hline ambient & 13.2 \\
$\mathrm{He}, 773 \mathrm{~K}$ & 13.0 \\
$\mathrm{H}_{2}, 773 \mathrm{~K}$ & 13.1 \\
$\mathrm{C}_{3} \mathrm{H}_{8}, 773 \mathrm{~K}$ & 13.0
\end{tabular}

${ }^{a}$ The edge position is defined as the first inflection point available in all spectra.

coordination is unchanged by propane reactions or by $\mathrm{H}_{2}$ treatment. Treatments in $\mathrm{He}, \mathrm{H}_{2}$, or $\mathrm{C}_{3} \mathrm{H}_{8}$ at $773 \mathrm{~K}$ also did not lead to a detectable shift in the absorption edge energy (Table 2), indicating that Co remained as divalent cations, in agreement with the TPR results, which showed that $\mathrm{Co}^{2+}$ species in $\mathrm{Co} /$ $\mathrm{H}-\mathrm{ZSM} 5$ do not reduce in $\mathrm{H}_{2}$ even at $1273 \mathrm{~K}$.

The radial structure functions of the $\mathrm{Co}$ species in $\mathrm{Co} / \mathrm{H}$ ZSM5 $(\mathrm{Co} / \mathrm{Al}=0.22)$ after treatment at $773 \mathrm{~K}$ in $\mathrm{He}, \mathrm{H}_{2}$, or $\mathrm{C}_{3} \mathrm{H}_{8}$ show weak features (Figure 11), suggesting that Co species reside in a non-uniform environment. $\mathrm{Co}^{2+}$ species assume a range of structures apparently as the result of the varying distances between framework oxygen atoms in the $\mathrm{Al}-\mathrm{Al}$ nextnearest neighbor pairs required to coordinate $\mathrm{Co}^{2+}$ cations. This range of possible structures is consistent with the proposed bridging structures of the Co monomers and dimers (Scheme 2 ), which require interactions with $\mathrm{Al}-\mathrm{Al}$ next-nearest neighbor sites and their associated framework oxygens. These oxygen atoms can assume a wide range of geometries, depending on the location of the $\mathrm{Al}-\mathrm{Al}$ pairs within the zeolite channel. This leads to static disorder around $\mathrm{Co}^{2+}$ cations and to diffuse scattering features in the radial structure functions. Similar radial structure functions were previously reported on Co/H-ZSM5 samples prepared by $\mathrm{CoCl}_{2}$ solid-state exchange, ${ }^{16}$ for which only chlorine neighbors in the first Co coordination shell were observed. These authors concluded that a wide range of $\mathrm{Co}-\mathrm{O}$ bond distances led to static distortion and prevented the detection of $\mathrm{O}$ nearest neighbors in the radial structure function.

One-shell fits to Co K-edge EXAFS from the fresh and dehydrated $\mathrm{Co} / \mathrm{H}-\mathrm{ZSM} 5$ samples were carried out using a single shell of oxygen neighbors generated with FEFF. EXAFS fits indicate octahedrally coordinated $\mathrm{Co}$, with single $\mathrm{Co}-\mathrm{O}$ distance of 2.086-2.096 $\AA$, in all fresh samples $(\mathrm{Co} / \mathrm{Al}=0.09-0.22)$ (Table 3). Following dehydration at $773 \mathrm{~K}$ in $\mathrm{He}, \mathrm{Co}$ in $\mathrm{Co} /$ $\mathrm{H}-\mathrm{ZSM} 5(\mathrm{Co} / \mathrm{Al}=0.09)$ has tetrahedral coordination by oxygen at single $\mathrm{Co}-\mathrm{O}$ distance of $1.989 \AA$ (Table 3 ). This is in agreement with our earlier finding based on analysis of the Co $\mathrm{K}$-edge near-edge features that Co coordination in Co/H-ZSM5 samples changes from octahedral to tetrahedral upon dehydration.

Propane Dehydrocyclodimerization on Co/H-ZSM5, HZSM5, and Zn/H-ZSM5. Reaction rates and product selectivities (at $\sim 11 \%$ propane conversion) on $\mathrm{Co} / \mathrm{H}-\mathrm{ZSM} 5$ are compared to those on H-ZSM5 and Zn/H-ZSM5 (with similar M/Al ratio) in Table 4 . The exchange of protons in H-ZSM5 with $\mathrm{Co}^{2+}$ cations significantly increased initial propane conversion turnover rates (per Al), from $9.6 \times 10^{-4} \mathrm{~s}^{-1}$ on $\mathrm{H}-\mathrm{ZSM} 5$ to 2.6 $\times 10^{-3} \mathrm{~s}^{-1}$ on Co-ZSM5 $(\mathrm{Co} / \mathrm{Al}=0.12)$ and to $4.2 \times 10^{-3} \mathrm{~s}^{-1}$ on $\mathrm{Co}-Z \mathrm{ZM} 5(\mathrm{Co} / \mathrm{Al}=0.22)$. Initial propane conversion turnover rates reflect the rates of propane cracking and propane dehydrogenation, both of which increased with increasing Co content (Table 4). Also, aromatics site-time yields (per Al) increased from $0.41 \times 10^{-4} \mathrm{~s}^{-1}$ on H-ZSM5 to $2.9 \times 10^{-4} \mathrm{~s}^{-1}$ on $\mathrm{Co} / \mathrm{H}-\mathrm{ZSM} 5(\mathrm{Co} / \mathrm{Al}=0.12)$. The selectivity to dehydrogenated products (propene and $\mathrm{C}_{6}-\mathrm{C}_{8}$ aromatics) increased, and 
SCHEME 2: Formation of Exchanged Hydrated $\mathrm{Co}^{2+}$ Cations

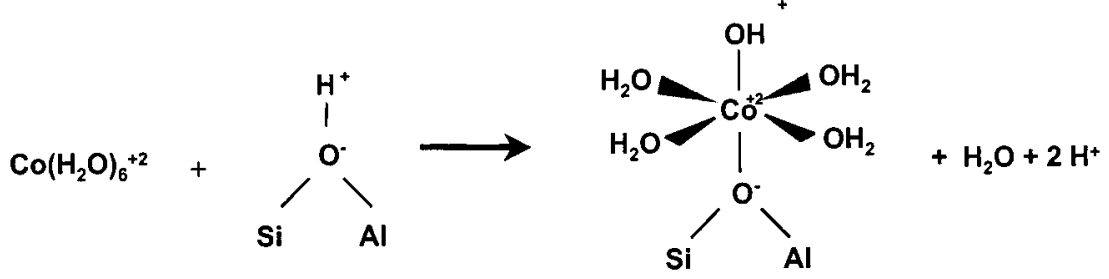

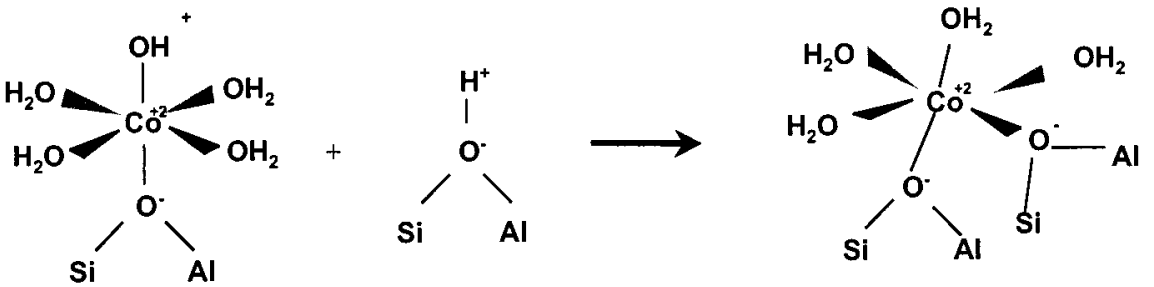

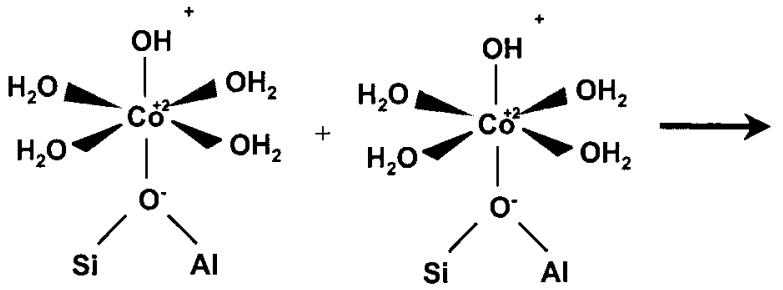

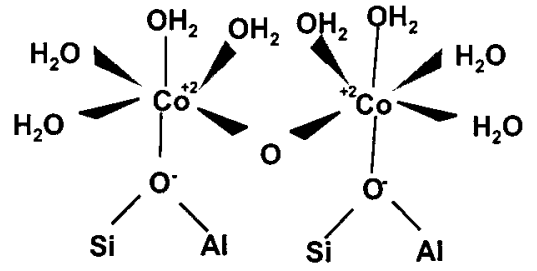

TABLE 3: One-Shell Fits to Co K-Edge EXAFS from Fresh and Dehydrated Co/H-ZSM5 Samples $(\mathrm{Co} / \mathrm{Al}=0.09-0.22)$ Using a Single Shell of Oxygen Neighbors Generated with FEFF $^{a}$

\begin{tabular}{lcccc}
\hline \multicolumn{1}{c}{ sample } & coord. no. & distance $/ \AA$ & $\sigma^{2} / \AA^{2}$ & $E_{0}$ shift/eV \\
\hline fresh, $\mathrm{Co} / \mathrm{Al}=0.09$ & 6.0 & 2.079 & 0.004 & -1.5 \\
fresh, $\mathrm{Co} / \mathrm{Al}=0.12$ & 6.4 & 2.090 & 0.011 & -1.0 \\
fresh, $\mathrm{Co} / \mathrm{Al}=0.17$ & 5.9 & 2.076 & 0.008 & -1.5 \\
fresh, $\mathrm{Co} / \mathrm{Al}=0.22$ & 6.5 & 2.096 & 0.011 & -1.2 \\
dehydrated, $\mathrm{Co} / \mathrm{Al}=0.09$ & 4.3 & 1.991 & 0.011 & 0.5
\end{tabular}

${ }^{a} \mathrm{Co}-\mathrm{O}$ coordination number decreases from about 6 to 4 upon sample dehydration, indicating a Co coordination change from octahedral to tetrahedral. $\sigma^{2}$ is the Debye-Waller factor.

TABLE 4: Propane Turnover Rates and Product Distribution on H-ZSM5, $1.1 \% \mathrm{Co} / \mathrm{H}-\mathrm{ZSM} 5$, and $1.3 \%$ Zn/H-ZSM5 [773 K, 21.5 kPa C ${ }_{3} \mathrm{H}_{8}$, Balance He]

\begin{tabular}{|c|c|c|c|}
\hline & H-ZSM5 & $\mathrm{Co} / \mathrm{H}-\mathrm{ZSM} 5$ & Zn/H-ZSM5 \\
\hline $\mathrm{M}(\mathrm{wt} \%)$ & 0.0 & Co (1.1) & $\mathrm{Zn}(1.3)$ \\
\hline $\mathrm{M} / \mathrm{Al}$ & 0.00 & 0.22 & 0.20 \\
\hline $\begin{array}{l}\text { initial propane turnover rate } \\
\quad\left(\text { per } \mathrm{Al}, 10^{-3} \mathrm{~s}^{-1}\right)\end{array}$ & 0.96 & 4.2 & 6.8 \\
\hline $\begin{array}{l}\text { initial cracking rate } \\
\quad\left(\text { per } \mathrm{Al}, 10^{-3} \mathrm{~s}^{-1}\right)\end{array}$ & 0.60 & 0.85 & 1.6 \\
\hline $\begin{array}{l}\text { initial propene formation rate } \\
\quad\left(\text { per } \mathrm{Al}, 10^{-3} \mathrm{~s}^{-1} \text { ) }\right.\end{array}$ & 0.36 & 3.0 & 4.5 \\
\hline propane conversion $(\%)$ & 11.4 & 11.2 & 11.2 \\
\hline $\begin{array}{l}\text { aromatics formation rate } \\
\quad\left(\text { per } \mathrm{Al}, 10^{-3} \mathrm{~s}^{-1}\right)\end{array}$ & 0.041 & 0.56 & 2.0 \\
\hline \multicolumn{4}{|l|}{ carbon selectivity (\%) } \\
\hline methane & 18.4 & 7.2 & 7.2 \\
\hline ethene & 31.5 & 17.0 & 14.7 \\
\hline ethane & 6.7 & 5.6 & 3.4 \\
\hline propene & 24.7 & 41.6 & 33.8 \\
\hline $\mathrm{C}_{6}-\mathrm{C}_{8}$ aromatics & 4.4 & 18.8 & 37.4 \\
\hline hydrogen selectivity (\%) & 9.1 & 23.5 & 31.3 \\
\hline
\end{tabular}

the selectivity to the hydrogen-rich lighter products (methane and ethane) decreased, with increasing Co content. These effects

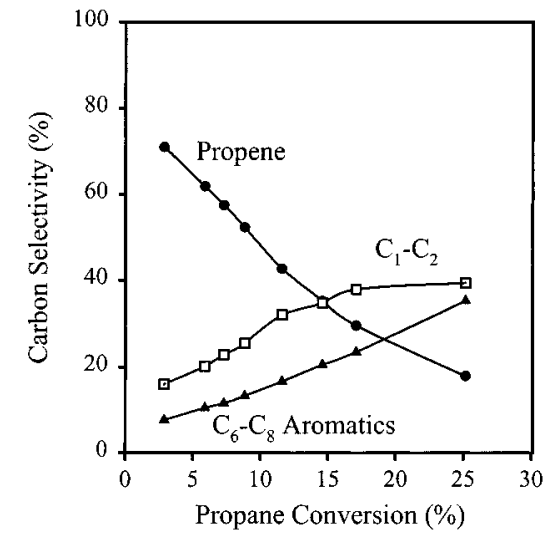

Figure 13. Product selectivities as a function of propane conversion on $\mathrm{Co} / \mathrm{H}-\mathrm{ZSM} 5\left[\mathrm{Co} / \mathrm{Al}=0.17,773 \mathrm{~K}, 21.5 \mathrm{kPa} \mathrm{C}_{3} \mathrm{H}_{8}\right.$, balance $\left.\mathrm{He}\right]$.

reflect the ability of $\mathrm{Co}^{2+}$ sites to desorb $\mathrm{H}$ atoms formed in $\mathrm{C}-\mathrm{H}$ bond activation steps as $\mathrm{H}_{2}$, as shown previously for $\mathrm{Zn}$ cations. ${ }^{1,6-8}$

The effects of contact time on conversion and selectivity are similar on $\mathrm{Co} / \mathrm{H}-\mathrm{ZSM} 5$ samples with a wide range of $\mathrm{Co} / \mathrm{Al}$ ratios; these trends are shown in Figure 13 for the sample with a $\mathrm{Co} / \mathrm{Al}$ of 0.17 . The selectivities to $\mathrm{C}_{1}-\mathrm{C}_{2}$ and propene products show a non-zero intercept suggesting that these products can form via primary cracking reactions of propane. Ethane and $\mathrm{C}_{6}-\mathrm{C}_{8}$ aromatics are secondary products; they show very low initial selectivities, which increase with increasing contact time. The observed decrease in the selectivity to propene with increasing contact time (Figure 13) is caused by its secondary conversion to aromatics. Aromatics form predominately via acidcatalyzed, cation-assisted secondary reactions involving oligomerization, dehydrogenation, and cracking of alkenes, as previously shown on $\mathrm{Zn}$ - and Ga-exchanged $\mathrm{H}-\mathrm{ZSM} 5$ catalysts. ${ }^{3,6-8}$

Initial propane conversion turnover rates and aromatics sitetime yields increased with increasing Co content (Figure 14), 


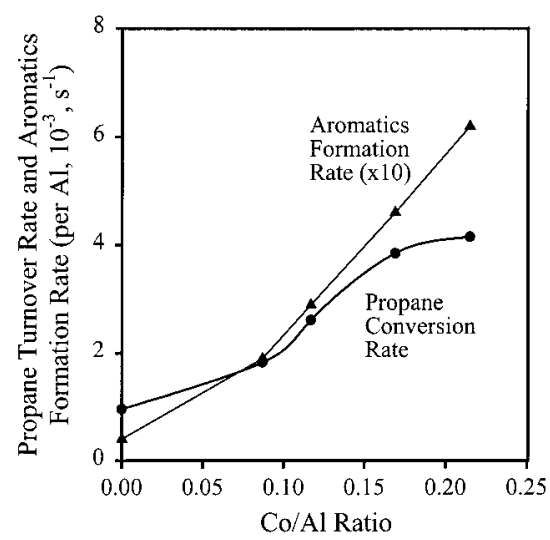

Figure 14. Initial propane turnover rate and aromatics site-time yield (at $10 \%$ propane conversion) as a function of $\mathrm{Co} / \mathrm{Al}$ ratio $[773 \mathrm{~K}, 21.5$ $\mathrm{kPa} \mathrm{C}_{3} \mathrm{H}_{8}$, balance $\left.\mathrm{He}\right]$.

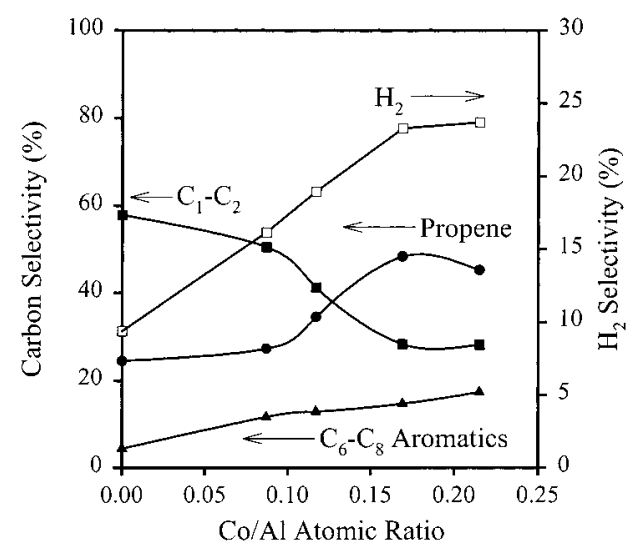

Figure 15. Product selectivities at $10 \%$ conversion as a function of $\mathrm{Co} / \mathrm{Al}$ ratio [773 K, $21.5 \mathrm{kPa} \mathrm{C}_{3} \mathrm{H}_{8}$, balance $\left.\mathrm{He}\right]$.

indicating that the rate-limiting step for propane dehydrogenation is catalyzed by Co cations. The effects of Co on the product selectivity are shown in Figure 15 at the same propane conversion $(\sim 10 \%) . \mathrm{C}_{1}-\mathrm{C}_{2}$ selectivity decreased and $\mathrm{C}_{6}-\mathrm{C}_{8}$ aromatics selectivity increased with increasing $\mathrm{Co}$ content, indicating that the addition of Co favors the formation of dehydrogenated products. Propene selectivities initially increased with increasing Co content, but then reached a constant value, apparently as the result of the ability of Co cations to increase also the rates of propene conversion to aromatics. $\mathrm{H}_{2}$ selectivities increased with increasing Co content (Figure 15), suggesting that $\mathrm{Co}^{2+}$ cations increase the rate of recombinative desorption of hydrogen to form $\mathrm{H}_{2}$. The rate-determining nature of hydrogen removal steps and the role of $\mathrm{Zn}$ cations as recombinative desorption sites were first proposed by Mole et al. ${ }^{1}$ The similar role of $\mathrm{Ga}$ and $\mathrm{Zn}$ cations, as sites for the recombinative desorption of $\mathrm{H}_{2}$, was later confirmed by kinetic and isotopic tracer studies. ${ }^{6,9}$ The higher propane conversion and aromatics formation rates and the higher selectivities to dehydrogenated products and to $\mathrm{H}_{2}$ observed as the Co content increases suggest a similar role of $\mathrm{Co}^{2+}$ cations in propane reaction pathways.

Initial propane dehydrogenation turnover rates (per $\mathrm{Al}$ ) (total propane turnover rate minus cracking rate) on Zn/H-ZSM5 (Zn/ $\mathrm{Al}=0.20 ; 5.2 \times 10^{-3} \mathrm{~s}^{-1}$ ) are higher than on Co/H-ZSM5 $\left(\mathrm{Co} / \mathrm{Al}=0.22 ; 3.3 \times 10^{-3} \mathrm{~s}^{-1}\right)$ (Table 4). Also, a higher selectivity to propene and a lower selectivity to $\mathrm{C}_{6}-\mathrm{C}_{8}$ aromatics are observed on $\mathrm{Co} / \mathrm{H}-\mathrm{ZSM} 5$ than on $\mathrm{Zn} / \mathrm{H}-\mathrm{ZSM} 5$. These results suggest that $\mathrm{Zn}^{2+}$ cations are more effective than $\mathrm{Co}^{2+}$ cations at catalyzing $\mathrm{H}_{2}$ recombinative desorption. This is consistent

\section{SCHEME 3: Consecutive Steps in Propane Dehydrogenation Reactions}

$$
\mathrm{C}_{3} \mathrm{H}_{8} \underset{-\stackrel{\mathrm{H}_{2}}{\longrightarrow}}{\longrightarrow} \mathrm{C}_{3} \mathrm{H}_{6} \underset{-1.5 \mathrm{H}_{2}}{\stackrel{\mathrm{k}_{2}}{\longrightarrow}} \frac{1}{2} \mathrm{C}_{6} \mathrm{H}_{6}
$$

with the $\mathrm{D}_{2}-\mathrm{OH}$ exchange results which showed the rates of $\mathrm{D}_{2}-\mathrm{OH}$ isotopic exchange are faster on Zn/H-ZSM5 than on $\mathrm{Co} / \mathrm{H}-\mathrm{ZSM} 5$ and the temperature of the HD evolution peak is lower on $\mathrm{Zn} / \mathrm{H}-\mathrm{ZSM} 5(584 \mathrm{~K}, \mathrm{Zn} / \mathrm{Al}=0.10)$ than on $\mathrm{Co} / \mathrm{H}-$ ZSM5 $(617 \mathrm{~K}, \mathrm{Co} / \mathrm{Al}=0.12)$. This indicates that $\mathrm{Zn}$ cations are more effective in recombining surface hydrogens formed in $\mathrm{C}-\mathrm{H}$ bond activation steps, leading to the more effective relief of kinetic bottlenecks and to higher propane turnover rates. As mentioned earlier, the primary product of propane dehydrogenation is propene, which undergoes secondary reactions to form aromatics, thus the reaction pathways can be considered as simple two-step consecutive reactions (Scheme 3), with $k_{1}$ and $k_{2}$ as the rate constants of each step. In the first step, each propane needs to lose only two hydrogens to form propene; in contrast, two propene molecules will have to each lose three hydrogens to form benzene, a representative aromatic product. As a result, $k_{2}$ is more sensitive than $k_{1}$ to the hydrogen removal capability of the cations. Since Co is not as effective as $\mathrm{Zn}$ in removing hydrogens, $k_{2}$ reflects these effects more sensitively than $k_{1}$; therefore, higher propene and lower aromatics selectivities are obtained on Co than on $\mathrm{Zn}$ when compared at similar propane conversion $(\sim 11 \%)$.

Structure and Density of Co Cations and Brønsted Acid Sites. Infrared and $\mathrm{D}_{2}-\mathrm{OH}$ exchange measurements (Figures 3 and 6) show that each $\mathrm{Co}$ atom replaces about $1.1-1.3$ protons during exchange. This stoichiometry suggests that some $\mathrm{Co}^{2+}$ cations replace two protons while others replace either one proton or none. $\mathrm{A} \mathrm{H}_{\text {removed }} / \mathrm{Co}$ value of two and charge neutrality requirements for $\mathrm{Co}^{2+}$ cations would require a bridging monomer interacting with two Al sites (Scheme 2). Such species may form via condensation of the initially exchanged $(\mathrm{Co}-\mathrm{OH})$ $\left(\mathrm{H}_{2} \mathrm{O}\right)_{n}{ }^{+}$with $\mathrm{OH}^{+}$(Scheme $\left.2 \mathrm{~b}\right)$. Isolated $(\mathrm{Co}-\mathrm{OH})^{+}$species, unable to condense, would not lead to the net removal of $\mathrm{H}$ atoms during exchange. $(\mathrm{Co}-\mathrm{O}-\mathrm{Co})^{2+}$ bridging dimers formed via condensation of two $(\mathrm{Co}-\mathrm{OH})^{+}$and interacting with two next-nearest neighbor $\mathrm{Al}$ sites would lead to the removal of only one $\mathrm{H}$ per exchanged $\mathrm{Co}^{2+}$ (Scheme 2c). The observed $\mathrm{OH}_{\text {removed }} / \mathrm{Co}$ ratio of $1.1-1.3$ (from $\mathrm{D}_{2}-\mathrm{OH}$ and infrared measurements) would suggest that it is likely that Co cations can exist as bridging $(\mathrm{Co}-\mathrm{O}-\mathrm{Co})^{2+}$ dimers, $\mathrm{Co}^{2+}$ monomers, and isolated $(\mathrm{Co}-\mathrm{OH})^{+}$. Reduction kinetic measurements showed that less than $1 \%$ of the Co atoms in these Co/H-ZSM5 samples can be reduced at temperatures below $1273 \mathrm{~K}$, indicating the essential absence of $\mathrm{CoO}_{x}$ clusters or crystallites. The unreducible nature of Co species suggests that they exist predominantly as $\mathrm{Co}^{2+}$ monomers and $(\mathrm{Co}-\mathrm{O}-\mathrm{Co})^{2+}$ dimers. $(\mathrm{Co}-\mathrm{OH})^{+}$are expected to be more reducible than bridging Co monomers or dimers, by analogy with the properties for similar $(\mathrm{Zn}-\mathrm{OH})^{+}$species detected in $\mathrm{Zn}$-exchanged Na-ZSM5 samples. $^{28}$

Both the bridging $\mathrm{Co}^{2+}$ monomers and $(\mathrm{Co}-\mathrm{O}-\mathrm{Co})^{2+}$ dimers shown in Scheme 2 require the presence of next-nearest neighbor $(\mathrm{NNN}) \mathrm{Al}-\mathrm{Al}$ pairs within a certain distance. As a result, the maximum extent of Co exchange depends on the concentration of such Al pairs. A previous study of the Al location in ZSM5 ${ }^{29}$ showed that a large fraction of $\mathrm{Al}$ atoms have $\mathrm{Al}$ next-nearest neighbors, residing within $4.2-6.5 \AA$ of each other for $\mathrm{Si} / \mathrm{Al}$ ratios of 11 to 19 . A more recent study, ${ }^{30}$ which excludes NNN pairs on opposite sides of a channel wall, concludes that $\mathrm{M}^{2+}$ / 
$\mathrm{Al}$ ratios of $\sim 0.15$ are possible for the $\mathrm{Si} / \mathrm{Al}$ ratio of 14.5 in our samples, if we assume that $\mathrm{Co}^{2+}$ cations exist exclusively as bridging monomers that span a distance of up to $5.5 \AA$ between framework oxygen atoms. The presence of $(\mathrm{Co}-\mathrm{O}-$ $\mathrm{Co})^{2+}$ dimers would increase the number of $\mathrm{NNN} \mathrm{Al}-\mathrm{Al}$ pairs because of the larger distance between $\mathrm{Al}$ pairs in these structures, consistent with the presence of isolated $\mathrm{Co}^{2+}$ monomers and dimers in samples with $\mathrm{Co} / \mathrm{Al}$ ratios as high as 0.22 .

Three types of exchanged $\mathrm{Co}^{2+}$ ions located at different cationic sites in $\mathrm{Co} / \mathrm{H}-\mathrm{ZSM} 5$ were suggested on the basis of a study using diffuse reflectance spectroscopy, ${ }^{31}$ and the predominant Co species reside at distorted six-member rings at the intersection of straight and sinusoidal channels. However, only monomeric Co species were considered in this study, while our results cast significant doubts about the significant abundance of such monomers. Our deuterium titration measurements of the residual proton density in H-ZSM5 after Co exchange showed the predominant presence of $(\mathrm{Co}-\mathrm{O}-\mathrm{Co})^{2+}$ dimers in all samples. Our XAS measurements also suggest that Co exists as a mixture of Co-oxo species with varying $\mathrm{Co}-\mathrm{O}$ bond distances and angles. The specific siting of each Co species, however, cannot be accurately determined due to the nonuniform nature of the distance and orientation in $\mathrm{Al}-\mathrm{Al}$ nextnearest neighbors in ZSM5.

Structural and Functional Requirements in Alkane Reactions Catalyzed by Cation-Exchanged H-ZSM5. The exchange of protons by Co increases propane conversion rates and the rates of formation of desired dehydrogenated products (propene and aromatics). Co/H-ZSM5 shows similar qualitative behavior to $\mathrm{Zn} / \mathrm{H}-\mathrm{ZSM} 5$ and $\mathrm{Ga} / \mathrm{H}-\mathrm{ZSM} 5$. The role of $\mathrm{Co}$ cations in desorbing the $\mathrm{H}$ atoms formed in $\mathrm{C}-\mathrm{H}$ bond activation steps as $\mathrm{H}_{2}$ is consistent with $\mathrm{D}_{2}-\mathrm{OH}$ measurements, which showed a substantial decrease in the activation energy for $\mathrm{D}_{2}$-dissociation when Co was exchanged onto H-ZSM5. Co cations decrease the concentration of surface hydrogen atoms during propane reactions and the hydrogen content in the products of this reaction. As a result, propene and aromatics selectivities increase and $\mathrm{C}_{1}-\mathrm{C}_{2}$ selectivities decrease with increasing Co content (Figure 15).

The anchoring of $\mathrm{Co}^{2+}$ cations at exchange sites places them in close proximity to acid sites, which may be required for the effective transfer of hydrogens, formed at acid sites during alkane dehydrogenation or olefin dehydrocyclization steps, to cations for removal as $\mathrm{H}_{2}$. The exchanged cations are isolated and coordinated strongly to the framework oxygen atoms. This appears to prevent their reduction and their ultimate agglomeration into $\mathrm{Co}^{0}$ clusters, which would otherwise occur for $\mathrm{CoO}_{x}$ crystallites during propane reactions at high temperatures. The formation of metal clusters, if they remained well-dispersed, would effectively catalyze the desorption of hydrogen, but to such an extent that it may lead to the extensive dehydrogenation of adsorbed intermediates and to the rapid formation of deactivating deposits.

\section{Conclusions}

Propane dehydrogenation rates on cobalt-exchanged H-ZSM5 catalysts $(\mathrm{Co} / \mathrm{Al}=0.09-0.22)$ are about 10 -fold higher than on H-ZSM5. The selectivities to propene, aromatics, and $\mathrm{H}_{2}$ are also higher as $\mathrm{Co}$ is exchanged onto $\mathrm{H}-\mathrm{ZSM} 5 . \mathrm{D}_{2}-\mathrm{OH}$ and infrared measurements showed that each $\mathrm{Co}^{2+}$ cation replaces about 1.1-1.3 zeolitic $\mathrm{H}^{+}$, suggesting the presence of monomer and dimer $\mathrm{Co}$ species bridging two next-nearest neighbor $\mathrm{Al}$ sites. No significant $\mathrm{H}_{2}$ consumption was detected up to 1273
$\mathrm{K}$ in any of the Co/H-ZSM5 samples, consistent with the absence of $\mathrm{CoO}_{x}$ crystallites, which reduce below $1000 \mathrm{~K}$. In situ near-edge X-ray absorption (XAS) studies indicate that Co species exist at cation exchange sites with tetrahedral coordination after dehydration and that they remain as divalent cations during exposure to $\mathrm{H}_{2}$ or to $\mathrm{C}_{3} \mathrm{H}_{8}$ at $773 \mathrm{~K}$. Near-edge and fine structure analysis of XAS data showed the presence of welldispersed $\mathrm{Co}^{2+}$ cations in all $\mathrm{Co} / \mathrm{H}-\mathrm{ZSM} 5$ samples $(\mathrm{Co} / \mathrm{Al}<$ 0.22 ), indicating the formation of similar exchanged species at all Co contents. The radial structure functions showed weak contributions from the coordination shells (beyond the initial $\mathrm{Co}-\mathrm{O}$ shell) around Co cations, a finding that we attribute to the nonuniform distributions of distances and orientations in $\mathrm{Al}-\mathrm{Al}$ next-nearest neighbors in ZSM5 structures.

Acknowledgment. This work was supported by the National Science Foundation (CTS-96-13632). X-ray absorption data were collected at Stanford Synchrotron Radiation Laboratory (SSRL), a facility operated by the United States Department of Energy (DOE), Office of Basic Energy Sciences, under contract DE-ACO03-76SF00515. The authors acknowledge Ms. Grace $\mathrm{J}$. Yu for the experimental assistance in obtaining the results shown in Figures 13-15.

\section{References and Notes}

(1) Mole, T.; Anderson, J. R.; Creer, G. Appl. Catal. 1985, 17, 141

(2) Kitagawa, H.; Sendodo, Y.; Ono, Y. J. Catal. 1986, 101, 12 281

(3) Gnep, N. S.; Doyemet, J. Y.; Guisnet, M. J. Mol. Catal. 1988, 45,

(4) Iglesia, E.; Baumgartner, J. E.; Price, G. L. J. Catal. 1992, 134, 549.

(5) Ono, Y. Catal. Rev.-Sci. Eng. 1992, 34, 179

(6) Biscardi, J. A.; Iglesia, E. Catal. Today 1996, 31, 207.

(7) Biscardi, J. A.; Meitzner, G. D.; Iglesia, E. J. Catal. 1998, 179, 192.

(8) Biscardi, J. A.; Iglesia, E. J. Catal. 1999, 182, 117

(9) Biscardi, J. A.; Iglesia, E. J. Phys. Chem. B 1998, 102, 9284

(10) Sun, T.; Trudeau, M. L.; Ying, J. Y. J. Phys. Chem. 1996, 100, 13662 .

(11) Okada, O.; Tabata, T.; Kokitsu, M.; Ohtsuka, H.; Sabatino, L. M. F.; Belluussi, G. Appl. Surf. Sci. 1997, 121/122, 267.

(12) Desai, A. J.; Kovalchuk, V. I.; Lombardo, E.; d'Itri, J. L. J. Catal. 1999, 184, 396.

(13) Yu, S. Y.; Li, W.; Iglesia, E. J. Catal. 1999, 187, 257.

(14) Li, W.; Yu, S. Y.; Iglesia, E. Stud. Surf. Sci. Catal. 2000, 130, 899.

(15) da Cruz, R. S.; Mascarenhas, A. J. S.; Andrade, H. M. C. Appl. Catal. B 1998, 18, 223 .

(16) Jentys, A.; Lugstein, A.; Vinek, H. J. Chem. Soc., Faraday Trans. 1997, 93, 4091.

(17) Verberckmoes, A. A.; Weckhuysen, B. M.; Pelgrims, J.; Schoonheydt, R. A. J. Phys. Chem. 1995, 99, 15222.

(18) Borry, R. W.; Kim, Y. H.; Huffsmith, A.; Reimer, J. A.; Iglesia, E. J. Phys. Chem. B 1999, 103, 5787.

(19) Kubelka, P.; Munk, F. Z. Tech. Phys. 1931, 12, 593.

(20) Barton, D. Ph.D. Dissertation, University of California, Berkeley, 1998.

(21) Ressler, T. WinXAS97 (version 1.2) 1998,

(22) Li, W.; Meitzner, G. D.; Borry, R. W.; Kim, Y. H.; Iglesia, E. Stud. Surf. Sci. Catal. 2000, 130, 3621

(23) Campbell, S. M.; Bibby, D. M.; Coddington, J. M.; Howe, R. F.; Meinhold, R. H. J. Catal. 1996, 161, 338.

(24) $\mathrm{Pu}, \mathrm{S}$. B.; Inui, T. Zeolites 1997, 19, 452.

(25) Moen, A.; Nicholson, D. G.; Ronning, M.; Lamble, G. M.; Lee, J. F.; Emerich, H. J. Chem. Soc., Faraday Trans. 1997, 93, 4071

(26) Jiang, T.; Ellis, D. E. J. Mater. Res. 1996, 11, 2242.

(27) Bearden, J. A.; Burr, A. F. Rev. Mod. Phys. 1967, 29, 125.

(28) Biscardi, J. A.; Iglesia, E. Phys. Chem. Chem. Phys. 1999, 1, 5753.

(29) Feng, X.; Hall, W. K. Catal. Lett. 1997, 46, 11.

(30) Rice, M. J.; Bell, A. T.; Chakraborty, A. J. Catal. 1999, 186, 222.

(31) Dedecek, J.; Kaucky, D.; Wichterlova, B. Microporous Mesoporous Mater. 2000, 35-36, 483. 